\title{
T cell therapy in combination with Vemurafenib in BRAF mutated metastatic melanoma patients
}

\author{
Troels Holz Borch ${ }^{1 *}$, Rikke Andersen², Per Kongsted ${ }^{1}$, Özcan Met ${ }^{1}$, Mads Hald Andersen ${ }^{1}$, Per thor Straten ${ }^{1}$, \\ Marco Donia', Inge Marie Svane ${ }^{2}$ \\ From Society for Immunotherapy of Cancer 29th Annual Meeting \\ National Harbor, MD, USA. 6-9 November 2014
}

\section{Background}

Adoptive $\mathrm{T}$ cell therapy (ACT) with tumor infiltrating lymphocytes (TIL) has proven to be a powerful treatment option for patients with metastatic melanoma, even when heavily pretreated, with response rates of approximately $50 \%$ and durable complete responses in about $15 \%$. However, there is still a need for improving TIL efficacy and a promising strategy is combination with immunomodulating agents. One such is Vemurafenib (Vem), a selective BRAF inhibitor, which has been shown to induce objective responses in about $50 \%$ of

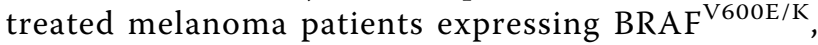
improving progression-free survival and overall survival compared to standard chemotherapy. In addition to the direct anti-cancer effect, Vem has been shown to increase $\mathrm{T}$ cell infiltration into tumors, up-regulate melanoma antigen expression and increase the frequency of TIL recognizing autologous melanoma cells. Combining TIL treatment and Vem is currently being investigated in other clinical trials testing different treatment schedules (ClinicalTrials.gov Identifier: NCT01659151 and NCT01585415).

\section{Methods}

A total of 12 patients will be included in this Phase II trial primarily to investigate safety when combining ACT and Vem. Secondarily, clinical responses will be evaluated according to RECIST and extensive immune monitoring will be performed.

Patients will receive Vem orally $960 \mathrm{mg}$ BID one week prior to excision of tumor material for $\mathrm{T}$ cell generation and continue this treatment until hospital admission. The patients will be hospitalized one week prior to TIL infusion in order to follow a preparative lymphodepleting

${ }^{1}$ Center for Cancer Immunotherapy, Herlev, Denmark

Full list of author information is available at the end of the article regimen consisting of Cyclophosphamide $60 \mathrm{mg} / \mathrm{kg}$ for 2days and Fludarabine $25 \mathrm{mg} / \mathrm{m}^{2}$ for 5 days. TIL infusion typically consists of $5-10 \times 10^{10} \mathrm{~T}$ cells and patients are subsequently treated with continuous interleukin-2 infusion following the decrescendo-regimen for 5 days.

Patients will be evaluated 6 weeks after TIL infusion and continuously thereafter.

\section{Results}

Patient accrual will start September 2014.

\section{Authors' details}

${ }^{1}$ Center for Cancer Immunotherapy, Herlev, Denmark. ${ }^{2}$ Center for Cancer Immune Therapy, Dept. of Hematology and Dept. of Oncology, Copenhagen University Hospital, Herlev, Denmark, Herlev, Denmark.

Published: 6 November 2014

doi:10.1186/2051-1426-2-S3-P67

Cite this article as: Borch et al:: T cell therapy in combination with Vemurafenib in BRAF mutated metastatic melanoma patients. Journal for ImmunoTherapy of Cancer 2014 2(Suppl 3):P67.

Submit your next manuscript to BioMed Central and take full advantage of:

- Convenient online submission

- Thorough peer review

- No space constraints or color figure charges

- Immediate publication on acceptance

- Inclusion in PubMed, CAS, Scopus and Google Scholar

- Research which is freely available for redistribution 